\title{
Determining the Economic Value of Historic Urban Districts through the use of the Hedonic Pricing Model: Ankara Castle District
}

\author{
Kentsel Tarihî Semtlerin Ekonomik Değerlerinin Hedonik \\ Fiyatlandırma Modeli ile Tespiti: Ankara Kalesi Semti
}

\author{
Leila AKBARISHAHABI \\ Asst. Prof., Cappadocia University, Faculty of Architecture, Design and Fine Arts, Department of City and Regional Planning, \\ Nevşehir, Turkey \\ Dr. Öğretim Üyesi, Kapadokya Üniversitesi, Mimarlık, Tasarım ve Güzel Sanatlar Fakültesi, Şehir ve Bölge Planlama Bölümü, \\ Nevşehir, Türkiye \\ leila.akbarishahabi@kapadokya.edu.tr \\ ORCID ID: 0000-0002-0547-7874
}

DOI: $10.5505 /$ jas.2021.30301

\begin{abstract}
Historic districts, which are an essential source of a society's historical and sociocultural values, have a semantic value for urban residents. However, the cultural identity of these areas and the semantic values they offer to people are often ignored nowadays in urban design and planning studies. This study aims to reveal the desire of many people to live closer to historic districts, and to encourage local governments to be more aware of the need to conserve these urban areas due to their value as part of a local identity. As historic districts are not normally on the market, determining their semantic value is a complex process, but one that can be achieved with the Hedonic Pricing model. In this study, the effect on house prices of being close to the historic district of Ankara Castle was examined with the help of this Model. In the study, a total of 422 houses was examined, all of which were located within a radius of 1500 meters from the district of Ankara Castle, and the effect of the distance to Ankara Castle on the price of the houses was evaluated. According to the results, the desire to live close to the district was reflected in higher house prices. Houses located within a 500 meter radius of Ankara Castle are sold at an average of $34.3 \%$ more than similar houses farther away. It was also found that the price of houses decreased by $5 \%$ with each additional 100m of distance away from the district of Ankara Castle.
\end{abstract}

Keywords: Conservation, Historic districts, Hedonic Pricing Model, Ankara Castle

\section{$\ddot{O} z$}

Bir toplumun tarihsel ve sosyokültürel değerlerinin temel kaynağı olan tarihî semtler, kentliler için anlamsal bir değere sahiptir. Ancak günümüzde bu alanların kültürel kimliği ve insanlara sundukları anlamsal değerler kentsel tasarım ve planlama çalıșmalarında göz ardı edilmektedir. Bu çalı̧̧ma, insanların tarihî semtlere daha yakın yaşama isteklerini ortaya çıkarmayı ve yerel yönetimlerin bu alanların kentsel dokuda yerel bir kimlik olarak korunması konusundaki farkındalıklarını artırmayı amaçlamaktadır. Tarihî semtler piyasa dışı ürünler olduğundan, anlamsal değerlerinin belirlenmesi karmaşık bir süreçtir. Hedonik Fiyatlandırma Modeli, piyasa dışı ürünlerin değerlendirilmesinde kullanılan bir yöntemdir. Çalışmada, tarihî bir semt olarak Ankara Kale semtine yakınlğın konut fiyatlarına etkisi bu model yardımıyla incelenmektedir. Bu kapsamda, Ankara Kale semtinin 1500 metre yarıçapında yer alan toplam 422 konut incelenmiş ve Ankara Kalesine olan mesafenin konut fiyatı üzerindeki etkisi değerlendirilmiştir. Elde edilen sonuçlara göre, Ankara Kale semtine yakın yaşama ve bunun için ödeme yapma isteği dolaylı olarak konut fiyatlarının artı̧̧ına neden olmuştur. Ankara Kalesinin 500 metrelik yarıçapında yer alan konutlar, uzaktaki benzer konutlara göre \% 34,3 daha fazla fiyatla satılmaktadır. Ayrıca, Ankara Kale semtine yakın konutların fiyatları her 100 metrede bir uzaklaştıkça \% 5 azalmaktadır.

Anahtar sözcïkler: Koruma, Tarihî semtler, Hedonik Fiyatlandırma Modeli, Ankara Kalesi, Ankara 


\section{Introduction}

A city can be considered as today's dominant form of settlement, and can be defined as consisting of spaces that is more than simply a concrete area. A city is a place where human thoughts have been reflected throughout history within physical places (Lefebvre, 1991). These spaces, which make up the spirit of the city, are defined as being assets which provide cultural sustainability from the past to the present. These cultural heritage assets can be perceived as being social values which reflect urban identity (Castells, 2009). Making correct decisions to conserve cultural heritage creates sustainability in the historical characteristics of the city, as well as strengthening urban identity. In this respect, the protection of cultural heritage is an essential part of urban planning studies. While conserving cultural heritage helps to increase social unity, cultural continuity, a sense of belonging, and satisfaction, it also leads to sustainable urban development. However, in the urban design and planning studies decisions taken by experts and governments, the cultural identity of historic districts and the semantic values they offer to people are often ignored, and the historical and cultural characteristics of these areas are usually not sufficiently protected. The Hacı Bayram Mosque and the Temple of Augustus in Ankara are examples of such projects (Tunçer, 2019).

This study aims to reveal the desire of many people to live closer to historic districts, and to encourage local governments to be more aware of the need to conserve these urban areas due to their value as part of the local identity. This is an essential and complex process for revealing the importance of the cultural heritage for society, and its semantic expression in preparing urban conservation plans. Historic districts in cities have cultural heritage characteristics, and as these districts are not normally on the market, determining their semantic values is a complex process. However, valuation can be achieved with the Hedonic Pricing Model (HPM), a widely used method for evaluating non-market products. This model explains the effect of each heterogeneous feature, such as houses that provide different levels of benefit or satisfaction to the user. In this model, the impact of an implicit value, such as the semantic value on heterogeneous benefit, increases the economic value of the house and thus makes semantic value measurable (Rosen, 1974).

This study emphasizes the importance of the Ankara Castle, a historical symbol which dominates the city of
Ankara from a strategic hill. The walls of this valuable heritage site, which is essential for locals, were at one time in danger of collapsing due to careless interventions, although the castle is now under protection. It is hoped that revealing the semantic value of this castle and its surroundings for local people will encourage suitable decisions to be taken in conservation projects. The study finds that the prices of the houses close to the historic district of Ankara Castle are higher than similar houses which are further away. This is due to increased demand for the area due to its historical and cultural value. The effect of proximity to the district on house prices was analyzed using the Hedonic Pricing model, with the data obtained from the online real estate agent being evaluated in the methodology section, along with examination of the HPM. According to the results, the desire to live close to the district of Ankara Castle, and the willingness to pay for the privilege, indirectly increase house prices. Houses located within a 500 meter radius of Ankara Castle are sold at an average of $34.3 \%$ more than similar houses farther away. It was also seen that the price of houses decreased by $5 \%$ with each additional $100 \mathrm{~m}$ distance from the district.

The present study is initially comprised of a detailed literature review of the concept of cultural heritage, the importance of the cultural and historic districts of cities, and the Hedonic Pricing Model structure. Very few studies were found during the review of the literature that reveal the qualitative value of cultural heritage, and so it is felt that this study will make a scientific contribution to the literature.

\section{Conceptual Framework}

\section{Cultural Heritage}

Cultural heritage is an essential source of a society's historical and sociocultural values (Throsby, 2003; Peacock, 1998, Falck, Fritsch and Heblich, 2011). According to a UNESCO's definition, cultural heritage has symbolic, historical, artistic, aesthetic, cultural, scientific, and social values (UNESCO, 2009), with every society's lifestyle and values, rituals, traditions, beliefs, and history being hidden in the society's cultural heritage (Feary, Brown, Marshall, Lilley, Mckinnon and Verschuuren, 2015). Cultural heritage that has semantic value is defined in two groups as having tangible (buildings, places, sites, archaeological artifacts) and intangible assets (rituals, expressions, knowledge, and skills that are accepted by the society as 
part of its cultural heritage) (Throsby, 2001). Tangible assets are an essential part of cultural heritage, and are distinctive according to each city due to their historical, architectural, symbolic, semantic, educational, aesthetic, scientific, and memorial value (Junainah, Suriatini, Abdul Hamid and Thuraiya, 2017; Armitage and Irons, 2013; Vukonić, 2018; Zin, Suriatini, Junainah, Nurul, H.A.M. and Fatin Afiqah 2019; Merciu, Ianoş, Cercleux and Merciu, 2020; Taher Tolou Del, Sedghpour, and Kamali Tabrizi, 2020). These assets are more than just abstract locations, but consist of elements that define the identity and nature of a place (N. Schulz and M. Schulz, 1980).

Urban areas which contain old buildings, places, and sites deemed valuable for historical, cultural, or architectural reasons can be defined as being historic districts. Historic districts are recognized as being an academic term defined by law. According to a definition by Caves (2004):

A historic district is first an acknowledgment that the historic character of an area is derived not just from the qualities of individual properties, but from the way these properties developed over time, and are related to each other formally, functionally, socially, and through the area's roads and other infrastructure, and natural conditions, such as climate and topography.

Various terms are used to describe historic districts within the framework of national and international regulations. These terms include "conservation areas" (England), "historic centers" and "historic areas" (World Heritage Convention), "historic places" (Canada, which includes districts, but does not define them), "old areas" (1975 Declaration of Amsterdam), and "historic towns or urban areas" (1987 Washington Charter of the International Council of Monuments and Sites). In most countries, mechanisms to protect districts or historic areas lag considerably behind protections for individual properties. Besides the historical importance of the existing buildings and places in historic districts, a region should also have integrity, which is a term that describes the relative amount of historical texture remaining within a district. For example, according to the definition of a "historic district" in the United States, at least 40 percent of its buildings should help define the historical character of the area (Caves, 2004). According to Regulation No. 2863, which was applied in Turkey for the protection of cultural and natural assets, a protected area which requires collective protection for the entire area, is defined as the protection of more than one cultural or natural asset at the area scale. For a historic district to be declared as a protected area culturally, the quality and quantity of the immovable cultural assets in the area that need to be protected are determined, and the boundaries of the area are defined. Following this procedure, the historic district is declared as a protected area, taken under protection, and is given a new legal status. In Turkey, a historic district is called a "Historical Site" in terms of terminology. It is defined as a place where significant historical events occur and therefore should be protected (Law of Turkey, 1983).

\section{The Importance of Urban Historic Districts}

It can be said that the most critical aspect of historic districts is their semantic value, rather than their aesthetics and architecture. Such areas emerge from a common experience of the expression of collective identity and the symbolization of collective memories (Taher Tolou Del et al., 2020). Historic districts affect lives within society by establishing a semantic connection, and these areas can also determine the values of the community and so become a desirable place to live in (Díaz-Andreu, 2017). Such districts attract people's attention and earn their respect (Lamprakos, 2005). While they are in these areas, citizens feel proud (Noonan, 2007) and their sense of belonging to a place is enhanced (Lewicka, 2008). Moreover, the semantic values of the historical districts provide cultural education and appreciation (Throsby, 2006). It can therefore be seen that the conservation of these urban areas helps not only to protect the area, but also serves to strengthen urban identity and social unity, while increasing the quality of life and sense of belonging.

\section{The Economic Value of Historic Districts}

The conservation and maintenance of cultural heritage is one of the common goals of many countries (Snowball, 2008). Urban conservation projects have gained significant importance in recent years for their effectiveness in ensuring cultural sustainability with globalization and rapid urbanization. One of the initial steps in conserving these assets is to reveal their semantic values to the public, and to organize appropriate conservation and restoration projects.

A consideration of the semantic values of cultural heritage emphasizes the importance of conservation projects 
(Taher Tolou Del, 2020). However, the tangible value of these assets cannot be directly measured through a method of numerically measuring unquantifiable implicit values (Hicks and Queen, 2016). Instead, there are two methods of determining the value of cultural heritage: Use and NonUse values. Use-value measures active use in terms of the cultural heritage of a public property. In other words, usevalue is a measure of the provision of direct service and the receiving of a service fee from users in return. Non-Use value is a passive use-value that individuals volunteer to pay in recognition of the aesthetic and semantic value of a monument, building, or historic district (Throsby, 2012, Moro, Mayor, Lyons. and Tol, 2013).

Historic districts are cultural heritage as public properties. As they are not traded on the market, they can be valued according to individuals' tastes based on nonmarket valuation methods (Alberini and Longo, 2009). Such methods can provide a good indication of the community's value in terms of non-market outcomes (Baker and Ruting, 2014). The non-market evaluation method is conducted in two ways: "revealed-preference approach", which is an indirect method based on individuals' preferences, and "stated-preference", which is a method that asks questions to measure the willingness to pay (Navrud and Ready, 2002; Mason, 2002; Throsby, 2002; Champ, Boyle, and Brown, 2003; Alberini and Longo, 2009). Baker and Ruting's (2014) summarization of these methods can be seen in Table 1.
The validity of the preference methods mentioned is controversial. One problem is that unreliable estimates will be obtained from respondents who are insufficiently familiar with a property. However, if appropriate data is available, revealed preference methods can provide reliable estimates in the assessment process. It can therefore be said that good data on all relevant factors is required for these methods, and they are most informative when key assumptions are laid out and tested (Baker and Ruting, 2014).

The Hedonic Pricing Model has been selected as the most suitable method for this study's purpose and hypothesis. According to the hypothesis of this study, house prices increase with increased proximity to the district of Ankara Castle. In the study, the prices of houses located within a radius of 1500 meters from Ankara Castle District were examined, and the effect of the distance from Ankara Castle on the price of the house, by comparison of like with like, was evaluated through the Hedonic Pricing Model.

\section{Hedonic Pricing Model (HPM)}

\section{Structure of HPM}

The Hedonic Pricing Model (HPM) is a "revealed-preference approach" that measures the value of an amenity indirectly through a willingness to hypothetically pay for it (Xiao, 2017). According to HPM, each aspect of a heterogeneous amenity, such as housing, provides a dif-

Table 1. Non-Market Valuation Methods

\begin{tabular}{|c|c|c|}
\hline Method & Approach & Description \\
\hline \multirow[b]{2}{*}{$\begin{array}{l}\text { Stated preference method (In this method, } \\
\text { a sample group is asked, via a survey, how } \\
\text { much they value a particular amenity.) }\end{array}$} & $\begin{array}{c}\text { Contingent } \\
\text { valuation }\end{array}$ & $\begin{array}{l}\text { This approach usually involves asking people if } \\
\text { they would be willing to pay a certain amount } \\
\text { of money for a particular amenity. }\end{array}$ \\
\hline & Choice modelling & $\begin{array}{l}\text { This approach estimates implicit prices for } \\
\text { the attributes of an amenity. This is done } \\
\text { by choosing between options according to } \\
\text { different levels of attributes and acceptable } \\
\text { costs. }\end{array}$ \\
\hline \multirow{2}{*}{$\begin{array}{l}\text { Revealed preference method (This } \\
\text { method uses behavior observations to } \\
\text { evaluate non-market outcomes as if they } \\
\text { were market goods.) }\end{array}$} & Travel-cost model & $\begin{array}{c}\text { This model uses recreation expenditure and } \\
\text { travel time to estimate the value people place } \\
\text { on visiting a specific site. }\end{array}$ \\
\hline & $\begin{array}{l}\text { Hedonic pricing } \\
\text { model }\end{array}$ & $\begin{array}{l}\text { This model estimates the value of a multi- } \\
\text { attribute amenity by valuating individual non- } \\
\text { market attributes. }\end{array}$ \\
\hline
\end{tabular}

Source: Baker and Ruting, 2014. 
ferent level of benefit or satisfaction to the consumer. The model evaluates the relationship between the housing prices, and the distance of places such as historic districts and parks, to surrounding houses (Rosen, 1974). According to HPM, the amount of change in the properties of a product can fully reflect the price change of the product.

In this model, house price is considered as being the dependent variable and house properties as the independent variables. As a result of statistical regression between dependent and independent variables, the effect of house properties and factors on the price are determined. Independent variables consist of the structural and environmental properties of the house. As HPM can quantitatively explain the impact of environmental properties, such as public spaces, open green spaces, various transportation possibilities, urban facilities, and landscapes on housing prices, the model is able to measure the economic benefits of these environmental properties, while emphasizing the need for local people's support of sustainable urban development (Ahlfeldt and Maennig, 2010).

A house contains different properties, with the implicit prices of each of these different properties being measurable. These implicit prices reveal consumers' marginal willingness to pay (Goodman and Thibodeau, 2003; Baranzini, Ramirex, Schaerer and Thalmann, 2008; Lazrak, Nijkamp, Rietveld and Rouwendal, 2014). When expressed as an equation, the structure of the estimated HP model is as follows.

$$
P=f(x, y)+\varepsilon
$$

$\mathrm{P}$ is price; $\mathrm{x}$ is a vector of house structural properties such as floor area and the number of rooms; $y$ is a vector of environmental properties such as proximity to a Metro Station, while proximity to the nearest historical monuments $\varepsilon$ is an error term.

\section{Earlier Studies}

HPM enables an assessment of the quantitative impact of cultural heritage and historic districts on the value of neighboring properties. The quantitative values obtained are of great importance to urban planners who must make decisions regarding conflicting plans to preserve the characteristic ambiance of the existing historical urban layout (Sopranzetti 2010; Lazrak et al., 2014). The positive impact of cultural heritage on surrounding housing prices has been demonstrated, with some of these studies being summarized in Table 2 .

\section{Methodology}

This study emphasizes the importance of historic districts and cultural heritage for residents and the need to conserve these assets. It is for this reason that the effect of the desire to live close to historic districts, namely the district of Ankara Castle in the Altındağ District of Ankara, on house prices was investigated. The hypothesis of the study was as follows: house prices increase in proportion to the proximity of the house to the district of Ankara. The Hedonic Pricing Model was used to examine this hypothesis. This model was selected because the effects of a specific variable can only be measured by keeping the impact of other variables that affect the price of a heterogeneous product, such as house, constant. In this study, this model was preferred because the variable examined was the effect of the distance of a house to the district of Ankara Castle on the price.

\section{Case Study}

Ankara Castle, located in the center of Ankara, was built on a defensive hill and a ledge of rock. The castle is surrounded by an outer wall. Ankara Castle was built around the beginning of the 2nd century $\mathrm{BC}$ as a fortification, and has been restored many times by the Romans, Byzantines, Seljuks, and Ottomans. The castle consists of an inner wall line which encloses approximately $350 \mathrm{~m}$ by $150 \mathrm{~m}$, and an outer wall line with towers approximately every $40 \mathrm{~m}$. The exact date of their construction is uncertain, but they were probably built after Ankara was captured and destroyed by the Persians in 622 . The interior walls are thought to be from the period of Constantine II., with the outer walls being built a little later (Foss, 1977). The castle is 110 meters high. The outer castle has nearly 20 towers, and the inner fort covers about 43,000 square meters. The highest point of the castle is Akkale, which is made of Ankara stone and has four floors. The inner castle has two large gates called the Outer Gate and the Hisar Gate. There is an inscription of the Ilkhanians and an inscription showing where the Seljuks repaired the doors. Various festivals are held every year at the castle. There are historical and cultural locations around the castle, such as structures from the Ottoman period, e.g. Pirinç Han, the Anatolian Civilizations Museum, and the Ankara Rahmi Koç Museum. This area is known as the historic district of Ankara, and Ankara Historic District Conservation Plan can be seen in Figure 1. 
L. Akbarishahabi, Determining the Economic Value of Historic Urban Districts through the use of the Hedonic Pricing Model: Ankara Castle District

Table 2. Earlier studies of HPM

\begin{tabular}{|c|c|}
\hline Study & Explanation \\
\hline $\begin{array}{l}\text { Ruijgrok } \\
\text { (2006) }\end{array}$ & $\begin{array}{l}\text { In this study conducted in the Netherlands, three different benefits of houses were considered: } \\
\text { comfort, recreational, and heritage. Using the Hedonic Pricing Model, the value of the comfort of } \\
\text { a house was determined. The results demonstrate that the historical features of houses and their } \\
\text { surroundings constitute } 5 \% \text { of the value of the property. }\end{array}$ \\
\hline $\begin{array}{l}\text { Moro et al. } \\
(2013)\end{array}$ & $\begin{array}{l}\text { In this study, the effect of distance and the density of cultural heritage within an area on housing } \\
\text { prices in Dublin, Ireland, was investigated through the use of a Hedonic Pricing Model. In the study, } \\
104 \text { regions were examined in terms of residential and neighborhood characteristics. According } \\
\text { to the results, cultural heritage sites such as historical buildings, monuments, and Martello towers } \\
\text { positively affected property prices, while it was revealed that archaeological sites had an adverse } \\
\text { effect on prices. }\end{array}$ \\
\hline $\begin{array}{l}\text { Lazrak et al. } \\
(2014)\end{array}$ & $\begin{array}{l}\text { In this paper, the effect of cultural heritage was analyzed in three complementary ways. First, the } \\
\text { authors measure the impact of a building being listed on its market price in the relevant area. } \\
\text { Secondly, the value that a listed heritage site has on nearby property was investigated. Finally, the } \\
\text { effect of historic districts on real estate prices was investigated. Findings revealed that buyers are } \\
\text { willing to pay an additional } 26.9 \% \text { to purchase a listed building, while surrounding houses are worth } \\
\text { an extra } 0.28 \% \text { for each additional listed building within a } 50 \text { meter radius. Houses sold within a } \\
\text { conservation area are seen to gain a premium of } 26.4 \% \text {, which confirms the 'historic ensemble' effect. }\end{array}$ \\
\hline $\begin{array}{l}\text { Hicks \& } \\
\text { Queen } \\
(2016)\end{array}$ & $\begin{array}{l}\text { This study uses the Hedonic Pricing Model in three regions, including historical sites in Virginia, to } \\
\text { examine the effects of historical districts on residential property values. Results indicate that residing } \\
\text { close to historical sites was valuable for buyers. }\end{array}$ \\
\hline $\begin{array}{l}\text { Li , Cheng, } \\
\text { Huang, and } \\
\text { Chi (2018) }\end{array}$ & $\begin{array}{l}\text { In this study, researchers used GIS-based data to examine how historic districts and cultural } \\
\text { heritage affect housing prices in Tainan city in Taiwan. According to the results, it was observed that } \\
\text { historical and cultural areas positively affect housing prices, and that the Hedonic Pricing Model is } \\
\text { an indicator of the economic value of cultural heritage. }\end{array}$ \\
\hline
\end{tabular}

\section{Data Collection}

The houses located within a radius of 1500 meters from the Ankara Castle district were examined in the present study. The house prices and their structural properties were obtained from an online real estate agent ${ }^{1}$ between June 2019 - June 2020 over a period of 12 months $^{2}$. The total number of valid samples ${ }^{3}$ was 422 . The study area distribution of the selected houses is provided in Figure 2.

The Geographical Information System (GIS) was used to calculate the accessibility and distance of the houses from the historic district and other social facilities used as vari- ables in the model. The descriptive statistical data relating to house properties ${ }^{4}$ is shown in Table 3.

As seen in Table 3, house prices vary between $\$ 15,571.42$ and $\$ 114,285.71$, with the mean selling price being $\$ 42,017.60$. The distance to the district of Ankara varies between 20 and 1495 meters, with the average distance being 846.709 meters.

\section{Hedonic Pricing Model (HPM)}

Three functional forms are often used in the hedonic pricing model: linear, semi-logarithmic, and logarithmic.

1 Data was collected from www.sahibinden.com, an online real estate agent in Turkey.

2 In order to eliminate price fluctuations due to the rapidly changing US Dollar / TL exchange rate, prices have been converted according to the Indicative USD / TL exchange rates of the Turkish Central Bank, and so US dollar amounts have been used in the model.

3 During the data collection process, attention was paid to the homogeneity of the data and only houses for sale were evaluated.

4 When the environmental characteristics of the houses are examined, it was determined that all the houses for sale have access to a bus stop, schools, banks, post offices and health institutions (less than $500 \mathrm{~m}$ on foot). This data is therefore not included as variables in the model. 


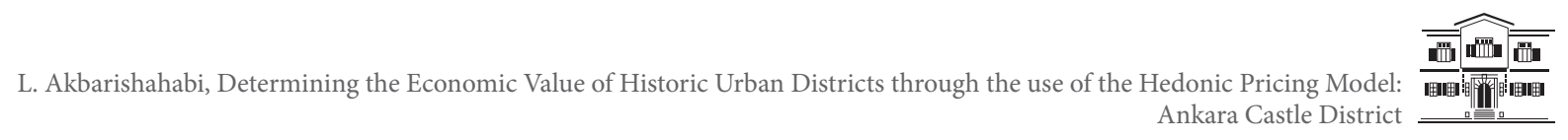

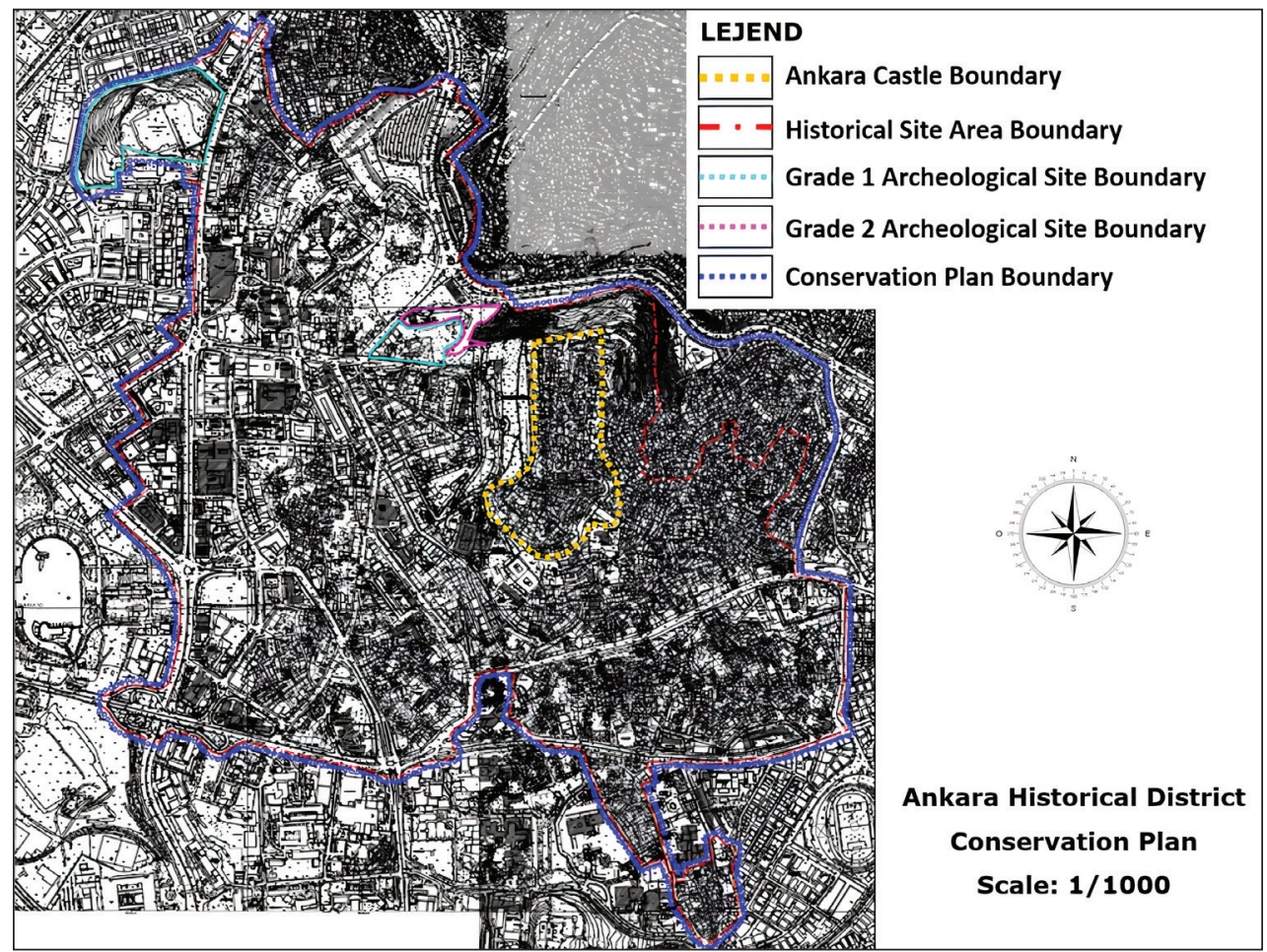

Figure 1. Ankara

Historic District

Conservation Plan.

Source: TMMOB, 2019.

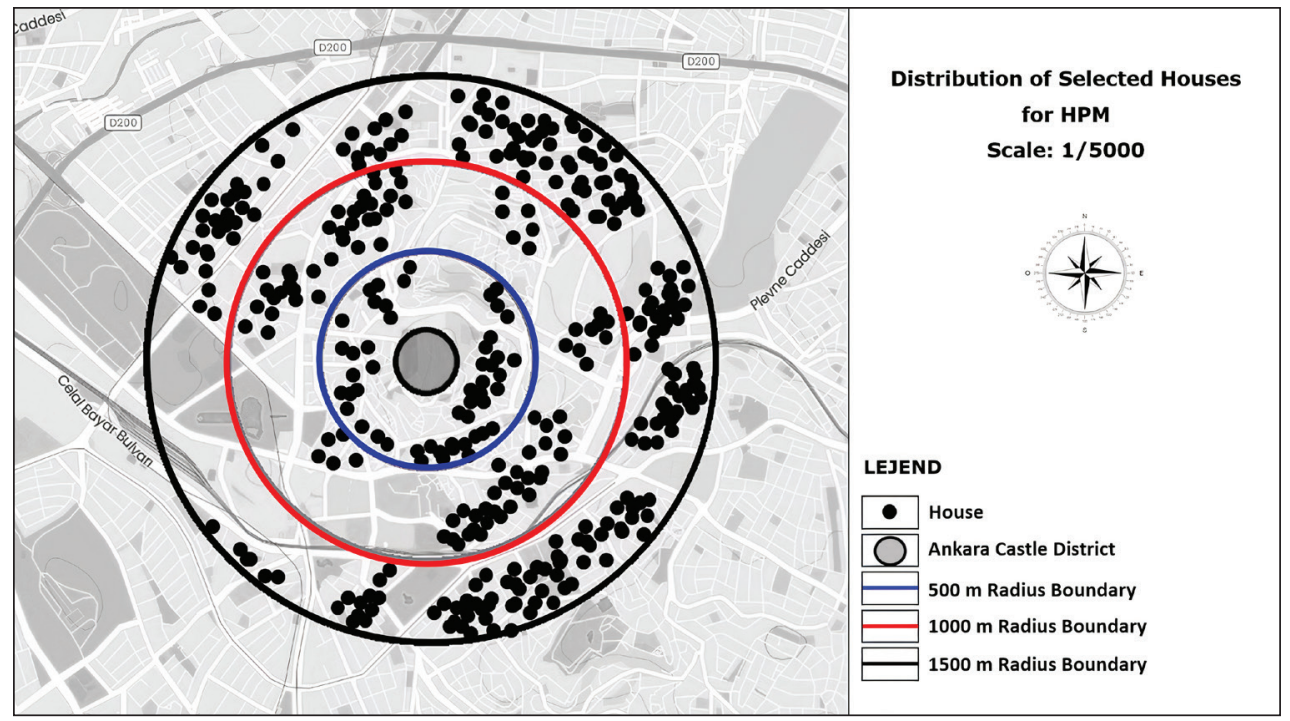

Figure 2. Distribution of Houses ${ }^{5}$

Source: Drawn on the map by Leila Akbarishahabi.

In the study, analysis was performed for all three models, and interpretation made of common meaningful variables. As a result of the comparison, the model with the highest $\mathrm{R}^{2}$ value was accepted as being the "General mod- el" and reported in the study. In this respect, the semilogarithmic (log-linear) function was interpreted as the meaningful model. The structure of the semi-logarithmic model is given below. The house prices are defined as

5 Map base was taken from the Mapcarta site (https://mapcarta.com/Ankara). 
L. Akbarishahabi, Determining the Economic Value of Historic Urban Districts through the use of the Hedonic Pricing Model: Ankara Castle District

Table 3. Descriptive Statistics

\begin{tabular}{|c|c|c|c|c|c|c|c|}
\hline & & $\mathrm{N}$ & $(\%)$ & Min. & Max. & Mean & $\mathrm{SD}$ \\
\hline \multicolumn{8}{|l|}{ Structural Properties } \\
\hline Sales Price $(\$)$ & & 422 & & 15571.42 & 114285.71 & 42017.60 & 17144.251 \\
\hline Floor space $\left(\mathrm{m}^{2}\right)$ & & & & 45.0 & 270.0 & 105.30 & 26.147 \\
\hline Number of rooms & & & & 1 & 6 & 2.687 & 0.711 \\
\hline Number of halls & & & & 0 & 2 & 0.990 & 0.119 \\
\hline Number of bathrooms & & & & 1 & 2 & 1.070 & 0.265 \\
\hline Floors in the house & & & & 0 & 12 & 3.610 & 2.719 \\
\hline Floors in the building & & & & 1 & 18 & 6.150 & 3.590 \\
\hline Heating system (Gas) & & & & 0 & 1 & 0.940 & 0.227 \\
\hline Presence of balcony & & & & 0 & 1 & 0.839 & 0.368 \\
\hline Presence of parking & & & & 0 & 1 & 0.654 & 0.476 \\
\hline Presence of elevator & & & & 0 & 1 & 0.512 & 0.501 \\
\hline Presence of view & & & & 0 & 1 & 0.573 & 0.495 \\
\hline \multicolumn{8}{|l|}{ Age of Residence } \\
\hline & $0-10$ (year) & 141 & 33.4 & & & & \\
\hline & $11-20$ (year) & 63 & 14.9 & & & & \\
\hline & $21-30$ (year) & 78 & 18.5 & & & & \\
\hline & 31 and over & 140 & 33.2 & & & & \\
\hline \multicolumn{8}{|l|}{ Environmental Properties } \\
\hline \multicolumn{8}{|l|}{ Proximity to Metro Station } \\
\hline & $0-500(m)$ & 51 & 12.09 & & & & \\
\hline & $501-1000(\mathrm{~m})$ & 134 & 31.75 & & & & \\
\hline & $1001-1500(m)$ & 237 & 56.16 & & & & \\
\hline \multicolumn{8}{|l|}{ Proximity to Park } \\
\hline & $0-500(\mathrm{~m})$ & 15 & 3.55 & & & & \\
\hline & $501-1000(m)$ & 15 & 3.55 & & & & \\
\hline & $1001-1500(m)$ & 392 & 92.90 & & & & \\
\hline \multicolumn{8}{|l|}{ Proximity to Cemetery } \\
\hline & $0-500(m)$ & 28 & 6.64 & & & & \\
\hline & $501-1000(m)$ & 65 & 15.40 & & & & \\
\hline & $1001-1500(\mathrm{~m})$ & 329 & 77.96 & & & & \\
\hline \multirow[t]{4}{*}{ Proximity to A.C.D. (m) } & & & & 20.0 & 1495.0 & 846.709 & 393.507 \\
\hline & $0-500(\mathrm{~m})$ & 62 & 14.70 & & & & \\
\hline & $501-1000(m)$ & 196 & 46.44 & & & & \\
\hline & $1001-1500(\mathrm{~m})$ & 164 & 38.86 & & & & \\
\hline
\end{tabular}


being the dependent variable, and the house's structural and environmental properties as the independent variable.

$\log ($ Price $)=\beta_{0}+\beta_{1} \log \left(X_{1}\right)+\beta_{2} \log \left(X_{2}\right)+\ldots+\beta_{n} \log \left(X_{n}\right)$

\section{Results}

The results of regression analysis of the prediction model are given in Table 4 . In this model (HPM-1), proximity to the district of Ankara Castle was examined over the distance variable. The dummy variable was defined as being the unit of distance $(\mathrm{m})$.
The variables included in the hedonic regression analysis were statistically analyzed at the $95 \%$ significance level ( $\mathrm{p}$ $<0.05$ ). According to F and Prob. (F) values, the model is meaningful and interpretable. According to the Hedonic Pricing Model rationale, other structural and environmental properties were kept similar between houses, and only the distance of houses to the district of Ankara castle was examined as a changed variable. According to the results of this model, the price of houses located close to the district of Ankara Castle decreased by $5 \%$ with each additional $100 \mathrm{~m}$. When this percentage is evaluated in

Table 4. HPM-1

\begin{tabular}{|c|c|c|c|c|}
\hline Variable & Coefficient & Std. Error & $\mathrm{t}$-Statistic & Prob. \\
\hline \multicolumn{5}{|l|}{ Structural Properties } \\
\hline Floor space $\left(\mathrm{m}^{2}\right)$ & 0.001973 & 0.000775 & 2.418456 & 0.0160 \\
\hline Number of rooms & 0.120898 & 0.025035 & 4.829159 & 0.0000 \\
\hline Number of halls & 0.340073 & 0.103824 & 3.275467 & 0.0011 \\
\hline Number of bathrooms & 0.084656 & 0.055124 & 1.535742 & 0.1254 \\
\hline Floor of residence & 0.011504 & 0.007349 & 1.565507 & 0.1185 \\
\hline Floors in the building & -0.015486 & 0.005353 & -2.892836 & 0.0040 \\
\hline Heating system (Gas) & 0.234777 & 0.058492 & 4.697651 & 0.0000 \\
\hline Presence of balcony & 0.126903 & 0.036330 & 3.493088 & 0.0005 \\
\hline Presence of parking & 0.006252 & 0.031940 & 0.195732 & 0.8449 \\
\hline Presence of elevator & 0.142406 & 0.034677 & 4.106695 & 0.0000 \\
\hline Presence of view & 0.025515 & 0.028414 & 0.897967 & 0.3697 \\
\hline Age of house & $-0,006866$ & 0.013670 & -0.502274 & 0.6157 \\
\hline \multicolumn{5}{|l|}{ Environmental Properties } \\
\hline Proximity to Metro Station & 0.072770 & 0.022506 & 2.789066 & 0.0055 \\
\hline Proximity to 'Gençlik' Park & 0.199815 & 0.029642 & 6.403548 & 0.0000 \\
\hline Proximity to 'Cebeci' Cemetery & -0.061121 & 0.024671 & -2.882780 & 0.0042 \\
\hline Proximity to 'Ankara Castle' & 0.000503 & $3.65 \mathrm{E}-05$ & 13.79378 & 0.0000 \\
\hline $\mathrm{C}$ & 10.73235 & 0.203897 & 52.63608 & 0.0000 \\
\hline R-squared & 0.685648 & \multicolumn{2}{|c|}{ Mean dependent var } & 10.57274 \\
\hline Adjusted R-squared & 0.669102 & \multicolumn{2}{|c|}{ S.D. dependent var } & 0.375273 \\
\hline S.E. of regression & 0.234781 & \multicolumn{2}{|c|}{ Akaike info criterion } & -0.023151 \\
\hline Sum squared residence & 22.37955 & \multicolumn{2}{|c|}{ Schwarz criterion } & 0.130214 \\
\hline Log likelihood & 20.88489 & \multicolumn{2}{|c|}{ Hannan-Quinn criterion } & 0.037454 \\
\hline F-statistic & 44.63993 & \multicolumn{2}{|c|}{ Durbin-Watson stat } & 0.900263 \\
\hline Prob. (F-statistic) & 0.000000 & & & \\
\hline
\end{tabular}

${ }^{*} \mathrm{P}<0.05$ Significance Level 
terms of average price, it is seen that there is a decrease of approximately $\$ 2100.88$ in the house price for every additional 100 meters. In the second model, the properties of being within 500 meters radius of the historic district were used as a dummy variable. The house prices inside the 0 - 500 meter radius were compared with those outside this area. The data obtained in terms of the HPM, and coefficients established is given in Table 5.

The variables included in the hedonic regression analysis were statistically analyzed at a 95\% significance level ( $\mathrm{p}$ $<0.05$ ). When F and Prob. (F) values are examined, it is determined that the model is meaningful and interpretable. According to the coefficients and significance levels, it can be observed that some variables do not significantly affect house prices. However, there are structural and environmental properties which do positively impact house prices, and others which have adverse effects. The coefficients and directions of the variables that have a statistically significant relationship on house prices at the level of $\mathrm{P}<0.05$ are shown in Figure 3.

When HPM-2 is examined, it is seen that there is no statistically significant relationship between the house price

Table 5. $H P M-2$

\begin{tabular}{|c|c|c|c|c|}
\hline Variable & Coefficient & Std. Error & t-Statistic & Prob. ${ }^{*}$ \\
\hline \multicolumn{5}{|l|}{ Structural Properties } \\
\hline Floor space $\left(\mathrm{m}^{2}\right)$ & 0.002183 & 0.000710 & 3.074311 & 0.0023 \\
\hline Number of rooms & 0.097597 & 0.023045 & 4.235038 & 0.0000 \\
\hline Number of halls & 0.373666 & 0.095074 & 3.930256 & 0.0001 \\
\hline Number of bathrooms & 0.094089 & 0.050375 & 1.867757 & 0.0625 \\
\hline Floor of residence & 0.011504 & 0.007349 & 1.565507 & 0.1185 \\
\hline Floors in the building & -0.012853 & 0.004929 & -1.998829 & 0.0463 \\
\hline Heating system (Gas) & 0.239385 & 0.053703 & 4.457600 & 0.0000 \\
\hline Presence of balcony & 0.141417 & 0.033280 & 4.249295 & 0.0000 \\
\hline Presence of parking & 0.041239 & 0.029467 & 1.399528 & 0.1624 \\
\hline Presence of elevator & 0.122602 & 0.031835 & 3.851113 & 0.0001 \\
\hline Presence of view & 0.014090 & 0.026036 & 0.541170 & 0.5887 \\
\hline Age of house & -0.006174 & 0.012500 & -0.493954 & 0.6216 \\
\hline \multicolumn{5}{|l|}{ Environmental Properties } \\
\hline Proximity to Metro Station & 0.087533 & 0.020751 & 4.218201 & 0.0000 \\
\hline Proximity to 'Gençlik' Park & 0.214968 & 0.027264 & 7.884759 & 0.0000 \\
\hline Proximity to 'Cebeci' Cemetery & -0.057427 & 0.022527 & -2.549238 & 0.0112 \\
\hline Proximity to 'Ankara Castle' & 0.343671 & 0.019681 & 17.46219 & 0.0000 \\
\hline $\mathrm{C}$ & 11.14545 & 0.192423 & 57.92151 & 0.0000 \\
\hline R-squared & 0.706954 & \multicolumn{2}{|c|}{ Mean dependent var } & 10.57274 \\
\hline Adjusted R-squared & 0.679582 & \multicolumn{2}{|c|}{ S.D. dependent var } & 0.375273 \\
\hline S.E. of regression & 0.215016 & \multicolumn{2}{|c|}{ Akaike info criterion } & -0.199032 \\
\hline Sum squared residence & 18.77013 & \multicolumn{2}{|c|}{ Schwarz criterion } & -0.045667 \\
\hline Log likelihood & 57.99572 & \multicolumn{2}{|c|}{ Hannan-Quinn criterion } & -0.138427 \\
\hline F-statistic & 58.42881 & \multicolumn{2}{|c|}{ Durbin-Watson stat } & 1.000387 \\
\hline Prob. (F-statistic) & 0.000000 & & & \\
\hline
\end{tabular}

${ }^{*} \mathrm{P}<0,05$ Significance Level 


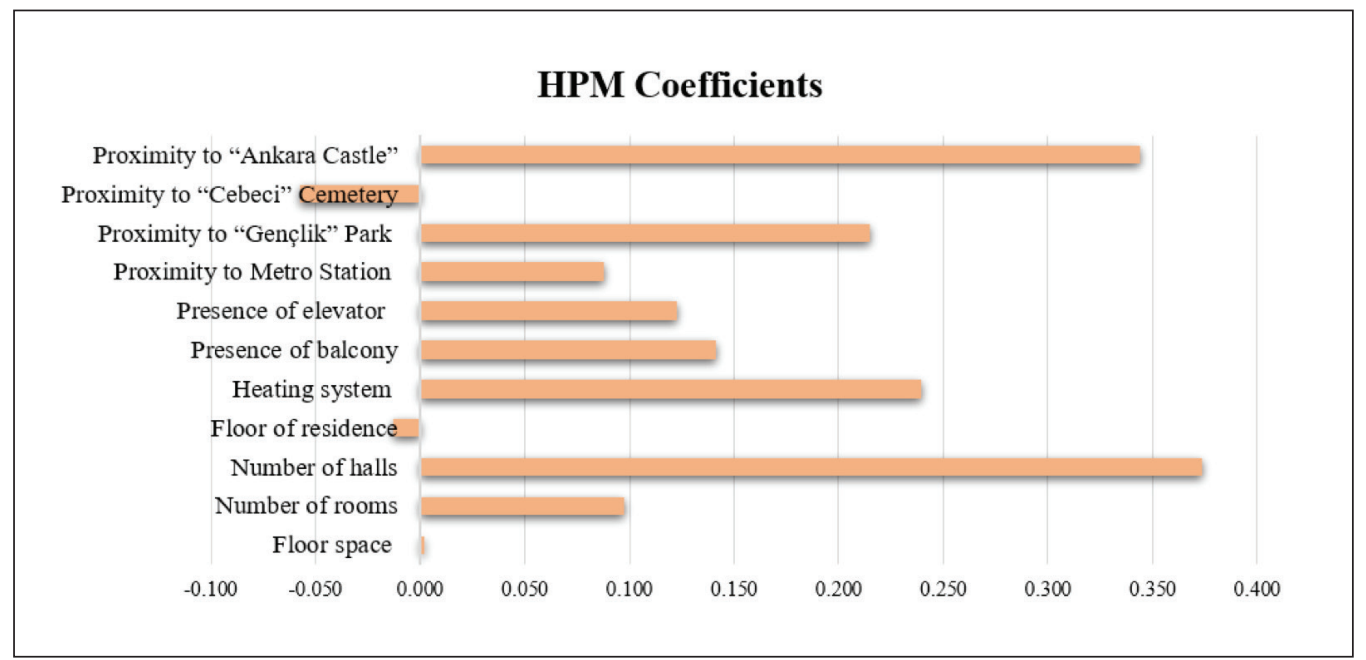

Figure 3. HPM Coefficients.

and the 'Number of Bathrooms', 'Floor of Residence', 'Presence of Parking', 'Presence of View' and 'Age of house' variables at the level of $\mathrm{p}<0.05$. However, when structural properties are considered, such as an increase in the area of the floor of a house by $1 \mathrm{~m}^{2}$, the price of the house increases by $0.2 \%$. Other relationships observed is that an increase in the number rooms in a house by 1 means that the house price increases by $9.7 \%$, an increase in the number of halls in a house by 1 means that the house price increases by $37.3 \%$, and an increase of 1 in the floor number in the building where the house is located means that the house price decreases 1.2\%. Furthermore, if the fuel system of a house is gas instead of coal, this increases the price of a house by $23.9 \%$, while the presence of a balcony in a house increases the price by $14.1 \%$, and the presence of an elevator increases the price by $12.2 \%$.

When the effects of environmental characteristics on house prices are examined in the model, a house closer than 500 meters to the Metro Station sells at an 8.7\% premium, as compared with a similar house at a further distance. A house closer than 500 meters to Gençlik Park sells at a $21.4 \%$ premium, as compared with a similar house at a further distance. A house further than 500 meters from Cebeci Cemetery sells at a 5.7\% premium, as compared with a similar house at a closer distance. Houses located within a 500 - meter radius of Ankara Castle are sold at a $34.3 \%$ premium, as compared to similar houses farther away. According to earlier studies, the proximity to cultural heritage increases house prices (Ruijgrok, 2006; Moro et al., 2013; Lazrak et al.,
2014; Hicks and Queen, 2016; Li et al., 2018), and the results obtained in this study confirm this hypothesis. It can therefore be seen that the Hedonic Pricing Model can be effectively used to quantitatively reveal the semantic values of cultural assets.

\section{Conclusion}

Historical urban districts form the cultural heritage and identity of a city, as well as having semantic values for local people. Such areas can help residents feel more satisfied with living in the city. In recent years, the conservation of cultural heritage has made significant progress, and various methods have been used to reveal the semantic value of these assets. To determine the semantic value of cultural heritage, measuring an individual's satisfaction with the existence of this heritage is one important method used. Cultural heritage is not traded in markets, and so consideration of values is only possible with nonmarket evaluation methods that develop the preferences of individuals. The Hedonic Pricing Model, which is a widely used non-market valuation methods, demonstrates that each characteristic of heterogeneous goods provides a different benefit or form of satisfaction to the consumer.

The aim of this study was to reveal the importance of historic districts for urban residents, and to emphasize the need of governments to protect these areas properly for improving the residents of the city satisfaction with their lives. In the study, the willingness of residents to pay for the privilege of living closer to the district of Ankara Castle was evaluated. The effect of the historic district's 
passive use-value on the surrounding house prices was examined, and HPM was used to determine the relationship between the accessibility of houses, in terms of the distance to the historic district, and the selling prices of the houses was evaluated.

The sales price of 422 houses was used as the dependent variable, while for independent variables, the structural and environmental properties of houses were evaluated. According to the coefficients of the predicted model, house prices increase if they are closer than 1500 meters to the district of Ankara Castle. It was also found that houses located within a 500-meter radius of Ankara Castle are sold at $34.3 \%$ more premium than similar houses farther away, and that price of houses close to the district of Ankara Castle decrease by 5\% for every 100 meters distance. It can be concluded that the outcomes from this study show that, since historic districts in the urban area are perceived as having value, residents are willing to pay higher prices for the privilege of living closer to cultural heritage and historic districts. Therefore, the conservation of historic districts in urban areas, through the application of suitable approaches, should be one of the priorities of urban planning. Not only will this enhance the quality of urban life and the satisfaction of residents, but it will also enable cultural and historical assets to be handed down to future generations.

\section{References}

Ahlfeldt, G.M. and Maennig, W. (2010). Substitutability and complementarity of urban amenities: external effects of built heritage in Berlin. Real Estate Economics, 38(2), 285323.

Alberini, A. and Longo, A. (2009). Valuing the cultural monuments of Armenia: Bayesian updating of prior beliefs in contingent valuation. Environment and Planning A, 41, $441-460$.

Armitage, L. and Irons, J. (2013). The Values of Built Heritage. Property Management, 31(3), 246-259.

Baker, R. and Ruting, B. (2014). Environmental policy analysis: a guide to non-market valuation. Canberra: Productivity Commission Staff Working Paper.

Baranzini, A., Ramirex, J., Schaerer, C. and Thalmann, P. (2008). Hedonic methods in housing markets: pricing environmental amenities and segregation. Berlin: Springer.

Castells, M. (2009). Power of identity: economy, society, and culture (2nd Edition). USA: Wiley-Blackwell.

Caves, R. W. (2004). Encyclopedia of the city. Routledge.
Champ, P.A., Boyle, K.J. and Brown, T.C. (2003). A Primer on nonmarket valuation kluwer academic. Boston, MA.

Díaz-Andreu, M. (2017). Heritage values and the public. Journal of Community Archaeology and Heritage, 4(1), 2-6.

Falck, O. Fritsch, M. and Heblich, S. (2011). The Phantom of the Opera: Cultural Amenities, Human Capital, and Regional Economic Growth. Labour Economics, 18,755-766.

Feary, S., Brown, S., Marshall, D., Lilley, I., Mckinnon, R., Verschuuren, B. and Wild, R. (2015). Earth's Cultural Heritage. In GL, Worboys, M, Lockwood, A, Kothari, S, Feary and I, Pulsford (Eds.), Protected area governance and management (p. 81-116). Australia: ANU Press.

Foss, C. (1977). Late Antique and Byzantine Ankara. Dumbarton Oaks Papers, 31, 70-72.

Goodman, A.C. and Thibodeau, Th. G. (2003). Housing market segmentation and hedonic prediction accuracy. Journal of Housing Economics, 12(3), 181-201.

Hicks, R.L. and Queen, B.M. (2016). Valuing historical and open space amenities with hedonic property valuation models. Agricultural and Resource Economics Review, 45(1), 44-67.

Junainah, M., Suriatini, I., Abdul Hamid, M.I. and Thuraiya, M. (2017). Assessment of heritage property values using multiple regression analysis and rank transformation regression. Environment-Behaviour Proceedings Journal, 2(6), 207-219.

Lamprakos, M. (2005). Rethinking Cultural Heritage: Lessons From Sana'a, Yemen, Traditional Dwellings and Settlements Review, 16(2),17-37.

Lazrak, F., Nijkamp, P., Rietveld, P., Rouwendal, J. (2014). The market value of cultural heritage in urban areas: an application of spatial hedonic pricing. Journal of Geographical Systems, 16, 89-114.

Lefebvre, H. (1991). The Production of space. London: Blackwell Publishing.

Lewicka, M. (2008). Place attachment, place identity, and place memory: restoring the forgotten city past. Journal of Environmental Psychology, 28(3), 209-31.

Law of Turkey (1983, 7 12). Law on the Conservation of Cultural and Natural Property-Law Number: 2863. Retrieved 2 23, 2021, from https://www.mevzuat.gov.tr/ MevzuatMetin/1.5.2863.pdf.

Li, D.L., Cheng, J.F., Huang, M. L. and Chi, Y.Y. (2018). Valuation of cultural heritage - a hedonic pricing analysis of housing via GIS-Based Data. Kyoto Japan, 20(4), 1910-1916.

Mason, R. (2002). Assessing values in conservation planning: methodological issues and choices. In M. De la Torre (Ed.), Assessing the values of cultural heritage (p. 5-30). Los Angeles: The Getty Conservation Institute.https:// www.getty.edu/conservation/publications_resources/pdf_ publications/pdf/assessing.pdf 
Merciu, F.C., Ianoș, I., Cercleux, A.L. and Merciu, G.L. (2020). Evaluation of the economic values of urban heritage in the central area of Ploiești Municipality. International Conference Knowledge-Based Organization, 26(2), 58-62. https://doi.org/10.2478/kbo-2020-0053

Moro, M., Mayor, K., Lyons, S. and Tol, R. S. J. (2013). Does the housing market reflect cultural heritage? A case study of greater Dublin. Environment and Planning A, 45, 28842903.

Navrud, S. and Ready, R.C. (2002). Valuing cultural heritage, applying environmental valuation techniques to historic buildings, monuments and artifacts. Northampton: Edward Elgar Pub.

Noonan, D. S. (2007). Finding an impact of preservation policies: price effects of historic landmarks on attached homes in Chicago, 1990-1999. Economic Development, 21(4), 17-33.

Peacock, A. (1998). Does the past have a future? The political economy of heritage. London: Institute of Economic Affairs.

Rosen, S. (1974). Hedonic prices and implicit markets: product differentiation in pure competition. Journal of Political Economy, 82, 34-55.

Snowball, J. (2008). Measuring the value of culture. Berlin: Springer.

Sopranzetti, B.J. (2010). Hedonic Regression Analysis in Real Estate Markets: A Primer. In C. F. Lee and C. A. Lee (Eds.), Handbook of quantitative finance and risk management (p.1201-1207). Berlin: Springer.

Ruijgrok, E. C. M. (2006). The three economic values of cultural heritage: a case study in The Netherlands. Journal of Cultural Heritage, 7(3), 206-213.

Taher Tolou Del, M.S, Sedghpour, B.S. and Kamali Tabrizi, S. (2020). The Semantic Conservation of Architectural Heritage: The Missing Values, Heritage Science, 8(70), 1-13.

Throsby, D. (2001). Economics and Culture. Cambridge: Cambridge University.
Throsby, D. (2002). Cultural capital and sustainability concepts in the economics of cultural heritage. In M. De la Torre (Ed.), Assessing the values of cultural heritage (p. 101-118). Los Angeles: The Getty Conservation Institute.

Throsby, D. (2003). Cultural capital. In R. Towse (Ed.), A Handbook of Cultural Economics (166-169). Cheltenham: Eward Elgar Publishing.

Throsby, D. (2006). Paying for the past: economics, cultural heritage, and public policy. In K. Anderson (Ed.). Joseph Fisher lecture in commerce, V. 51 (p. 1-13). Australia: The University of Adelaide.

Throsby, D. (2012). Heritage economics: a conceptual framework. In G. Licciardi and R. Amirtahmasebi (Eds.) The economics of uniqueness, investing in the historic city cores and cultural heritage assets for sustainable development (p. 45-74). Washington, D.C.: The World Bank.

TMMOB, (2019). Şehir Plancılar Odası; Çalıştay: Ulus Koruma Amaçli Imar Planı, Ankara. Retrieved from: https://www. spo.org.tr/genel/bizden_detay.php?kod=9866\&tipi $=$ 2\&sube $=1$

Tunçer, M. (2019). Korunamayan kültürel miras Hacı Bayram Camisi ve Augustus Tapınağı çevresi. Ankara: Gazi Kitabevi.

UNESCO. (2009). UNESCO Framework for Cultural Statistics. Montreal: UNESCO.

Vukonić, B. (2018). Similarities and differences of historical cities as tourism destinations. Acta Turistica, 30, 83-94.

Xiao, Y. (2017). Urban morphology and housing market. Singapour: Singapour Springer.

Zin, N. M., Suriatini, I., Junainah, M., Nurul, H.A.M. and Fatin Afiqah, Md. A. (2019). Critical determinants of heritage property value: a conceptual framework. Planning Malaysia, 17(1), 219 - 231. 
